\title{
Biochemical And Genetic Characteristics of Patients With Primary Carnitine Deficiency Identified Through Newborn Screening
}

\section{Yiming Lin}

Quanzhou Maternity and Children's Hospital

\section{Bangbang Lin}

Quanzhou Maternity and Children's Hospital

\section{Yanru Chen}

Quanzhou Maternity and Children's Hospital

\section{Zhenzhu Zheng}

Quanzhou Maternity and Children's Hospital

\section{Qingliu Fu}

Quanzhou Maternity and Children's Hospital

\section{Weihua Lin ( $\nabla$ ymlin0819@foxmail.com )}

Quanzhou Maternity and Children's Hospital https://orcid.org/0000-0002-7415-2758

\section{Weifeng Zhang}

Quanzhou Maternity and Children's Hospital

\section{Research Article}

Keywords: Primary carnitine deficiency, newborn screening, SLC22A5 gene, free carnitine, tandem mass spectrometry

Posted Date: October 11th, 2021

DOI: https://doi.org/10.21203/rs.3.rs-948430/v1

License: (c) (1) This work is licensed under a Creative Commons Attribution 4.0 International License. Read Full License

Version of Record: A version of this preprint was published at Orphanet Journal of Rare Diseases on December 1st, 2021. See the published version at https://doi.org/10.1186/s13023-021-02126-3. 


\section{Abstract}

Background: Primary carnitine deficiency (PCD) is an autosomal recessive disorder of the carnitine transportation that leads to impaired fatty acid oxidation. Large-scale studies on newborn screening (NBS) for PCD are limited. This study aimed to investigate the biochemical and genetic characteristics of patients with PCD detected by NBS.

Results: A total of 548,247 newborns were screened for PCD between January 2014 and June 2021, 1714 newborns had low free carnitine (CO) levels were called back and forty-nine patients were diagnosed with PCD. The latest incidence rate in Quanzhou, China was estimated to be 1 in 11,189 newborns. NBS results showed that all patients had varying degrees of decreased $\mathrm{CO}$ levels, while seven patients exhibited normal $\mathrm{CO}$ levels during recall review. All patients harbored biallelic pathogenic variants in the SLC22A5 gene. Nineteen distinct SLC22A5 variants were detected in the 49 patients, most of the detected variants were clustered in exons 1,4 , and 7 . The top eight variants together had an allele frequency of $86.73 \%$. The most common variant was c.760C >T (p.R254*) with an allele frequency of $31.63 \%$, followed by c.51C>G (p.F17L) (17.35\%) and c.1400C>G (p.S467C) (16.33\%). The C0 level of patients with N/N genotype was significantly lower than that of $\mathrm{M} / \mathrm{M}$ group. The $\mathrm{C} 0$ level of patients with genotypes of R254*/R254* and R254*/F17L were far lower than patients with genotype of R254*/S467C.

Conclusions: This study presented more than 500,000 NBS data with the latest incidence of $1: 11,189$ in Quanzhou area. The SLC22A5 variant spectrum in the selected southern Chinese population was updated. Patients with null variants were associated with low $\mathrm{CO}$ levels. It is necessary to combine genetic testing to improve screening efficiency due to PCD patients may have normal CO levels during NBS and recall review.

\section{Background}

Primary carnitine deficiency (PCD, OMIM \#212140) is an autosomal recessive disorder of the carnitine transportation that leads to impaired fatty acid oxidation. The causative gene, SLC22A5 (MIM\# 603377), was mapped to chromosome 5q31 and encodes organic cation transporter type 2 (OCTN2) [1, 2]. Patients with this defect experience continuous renal losses of carnitine, defective ketogenesis, and low serum carnitine levels resulting in muscle weakness and pain, as well as cardiomyopathy and arrhythmias [3]. The clinical presentation of PCD shows obvious variability ranging from no clinical symptoms to acute metabolic decompensation early in life, progressive hypertrophic cardiomyopathy later in life, or even sudden death from cardiac arrhythmia [4-7]. Lifelong high dose carnitine supplementation is recommended for patients with PCD regardless of the severity of presentation, and the long-term prognosis is favourable with timely treatment [8].

Newborn screening (NBS) is a useful preventive health measure for early diagnosis, it has been proven to be economically efficient. Given that PCD is a well-treatable metabolic disease and adverse symptoms can be prevented, PCD has been included into many NBS panels worldwide. NBS for PCD is done using 
tandem mass spectrometry (MS/MS), by measuring free carnitine (C0) levels below the cut-off value in dried blood spot samples. The diagnosis of PCD after NBS is mainly confirmed by mutational analysis of the SLC22A5 gene $[9,10]$.

Although several reports of PCD NBS in the Chinese population have been reported, the screened number and confirmed positive patients were relatively limited [11-13]. The expanded NBS program was implemented in Quanzhou, China since January 2014. So far, more than 500,000 newborns were screened for PCD. In this study, we reported our experience of NBS for PCD over eight years in southern China. We sought to determine the latest incidence, biochemical, and genetic features of PCD identified through NBS. Additionally, we attempted to investigate the relationship between genotype and biochemical phenotype of PCD patients.

\section{Methods}

\section{Study population}

From January 2014 to June 2021, a total of 548,247 newborns (309,684 males and 238,563 females) who were born in Quanzhou, Fujian province of China were screened using MS/MS in the NBS center at Quanzhou Maternity and Children's Hospital. All the screen-positive newborns and patients genetically diagnosed with PCD (compound heterozygous or homozygous for SLC22A5 pathogenic variants) were recruited for this study. This study was approved by the Ethical Committee of Quanzhou Maternity and Children's Hospital. Written informed consent was obtained from the parents of all patients.

\section{Nbs And Diagnostic Evaluation}

The specimen collection, delivery, and laboratory testing for NBS are as previously described [24]. Newborns with low $\mathrm{C} 0$ levels ( $\mathrm{C} 0<8.5 \mu \mathrm{mol} / \mathrm{L}$, cut-off value: $8-50 \mu \mathrm{mol} / \mathrm{L}$ ) were called back. Newborns who tested positive on the second screen were referred for further genetic analysis. Between January 2017 and December 2018, a second-tier newborn genetic screening targeting 17 SLC22A5 variants was added to our NBS program [19]. Targeted next-generation sequencing (NGS) was performed as previously described [27]. Definitive diagnosis was made based on abnormal $\mathrm{CO}$ levels and the presence of biallelic pathogenic variants in SLC22A5.

\section{Statistical Analyses}

All statistical analyses were done using SPSS 26.0 (SPSS Inc., Chicago, IL, USA). Data were expressed as median \pm standard deviation when normally distributed, as median (interquartile range) when nonnormally distributed. One-way ANOVA test and non-parametric test were used for statistic comparisons respectively. Differences between groups were considered statistically significant when $P<0.05$ (*P< $0.05 ; * \star P<0.01 ; * \star \star P<0.001$.) 


\section{Results}

\section{NBS for PCD}

Overall, during the study period 548,247 newborns were screened for PCD. NBS results showed that 1714 newborns had low C0 levels, yielding a positivity rate of $0.31 \%(1714 / 548,247)$. Forty-nine patients were diagnosed with PCD, the positive predictive value (PPV) was approximately $2.86 \%(49 / 1714)$. Consequently, the incidence rate in Quanzhou was estimated to be 1 in 11,189 newborns.

\section{Biochemical Features}

The initial NBS results showed that all patients had varying degrees of decreased C0 levels. The mean C0 level at NBS in this cohort was $4.16 \pm 1.78 \mu \mathrm{mol} / \mathrm{L}$ (range $1.63-8.25$, cut-off value: $8.5-50 \mu \mathrm{mol} / \mathrm{L}$ ). In comparison, seven patients (14.3\%) (no. 15, 16, 26, 27, 30, 37, and 42) exhibited normal C0 levels during recall review. The mean C0 level was increased to $4.69 \pm 3.01 \mu \mathrm{mol} / \mathrm{L}$ on the second screen (range 1.0514.27, cut-off value: $8.5-50 \mu \mathrm{mol} / \mathrm{L})$ (Table 1$)$. 
Table 1

Biochemical and genetic characteristics of 49 patients with PCD

\begin{tabular}{|c|c|c|c|c|c|c|}
\hline $\begin{array}{l}\text { Patient } \\
\text { no. }\end{array}$ & Gender & CO & $\begin{array}{l}\text { C0- } \\
\text { F1 }\end{array}$ & Genotype & & References \\
\hline 1 & Male & 4.61 & 6.29 & c.51C>G (p.F17L) & c. $1195 \mathrm{C}>\mathrm{T}(\mathrm{p} . \mathrm{R} 399 \mathrm{~W})$ & This study \\
\hline 2 & Female & 3.28 & 3.17 & c.51C>G (p.F17L) & c.51C>G (p.F17L) & This study \\
\hline 3 & Female & 2.37 & 1.05 & $\begin{array}{l}\text { c.338G>A } \\
\text { (p.C113Y) }\end{array}$ & c.760C >T (p.R254*) & This study \\
\hline 4 & Male & 7.65 & 5.04 & c.51C>G (p.F17L) & c. $1400 \mathrm{C}>\mathrm{G}(\mathrm{p} . \mathrm{S} 467 \mathrm{C})$ & This study \\
\hline 5 & Male & 3.75 & 3.19 & c.760C $>\mathrm{T}\left(\mathrm{p} . \mathrm{R} 254^{\star}\right)$ & c. $1400 \mathrm{C}>\mathrm{G}(\mathrm{p} . \mathrm{S} 467 \mathrm{C})$ & This study \\
\hline 6 & Male & 2.72 & 2.86 & c. $844 \mathrm{C}>\mathrm{T}\left(\mathrm{p} . \mathrm{R} 282^{\star}\right)$ & c. $1400 \mathrm{C}>\mathrm{G}(\mathrm{p} . \mathrm{S} 467 \mathrm{C})$ & This study \\
\hline 7 & Female & 2.54 & 2.29 & $\begin{array}{l}\text { c.695C>T } \\
\text { (p.T232M) }\end{array}$ & c.760C >T (p.R254*) & This study \\
\hline 8 & Male & 5.29 & 6.58 & c.51C>G (p.F17L) & c.1195C>T(p.R399W) & This study \\
\hline 9 & Female & 5.02 & 5.53 & c.428C>T (p.P143L) & c.428C>T (p.P143L) & This study \\
\hline 10 & Female & 1.63 & 1.67 & c.760C>T (p.R254*) & c.760C>T (p.R254*) & This study \\
\hline 11 & Male & 2.31 & 2.76 & c. $51 \mathrm{C}>\mathrm{G}(\mathrm{p} . \mathrm{F} 17 \mathrm{~L})$ & c. $1161 T>G\left(p . Y 387^{\star}\right)$ & This study \\
\hline 12 & Female & 3.49 & 3.52 & c.51C>G (p.F17L) & c.760C $>\mathrm{T}\left(\mathrm{p} . \mathrm{R} 254^{\star}\right)$ & $\begin{array}{l}\text { Lin et al. } \\
2020^{[10]}\end{array}$ \\
\hline 13 & Male & 1.96 & 1.73 & c.51C>G (p.F17L) & c.760C >T (p.R254*) & $\begin{array}{l}\text { Lin et al. } \\
2021^{[19]}\end{array}$ \\
\hline 14 & Female & 2.40 & 1.44 & c.760C $>\mathrm{T}\left(\mathrm{p} . \mathrm{R} 254^{\star}\right)$ & c.760C>T (p.R254*) & $\begin{array}{l}\text { Lin et al. } \\
2021^{[19]}\end{array}$ \\
\hline 15 & Male & 5.78 & 10.67 & c.760C $>\mathrm{T}\left(\mathrm{p} . \mathrm{R} 254^{\star}\right)$ & c.797C>T (p.P266L) & $\begin{array}{l}\text { Lin et al. } \\
2021^{[19]}\end{array}$ \\
\hline 16 & Male & 5.95 & 8.64 & $\begin{array}{l}\text { c.695C>T } \\
\text { (p.T232M) }\end{array}$ & c. $1160 A>G(p . Y 387 C)$ & $\begin{array}{l}\text { Lin et al. } \\
2021^{[19]}\end{array}$ \\
\hline 17 & Female & 7.27 & 6.66 & c. $760 \mathrm{C}>\mathrm{T}\left(\mathrm{p} . \mathrm{R} 254^{\star}\right)$ & c.797C>T (p.P266L) & $\begin{array}{l}\text { Lin et al. } \\
2021^{[19]}\end{array}$ \\
\hline 18 & Female & 5.58 & 5.59 & c.760C >T (p.R254*) & c. $1400 \mathrm{C}>\mathrm{G}(\mathrm{p} . \mathrm{S} 467 \mathrm{C})$ & $\begin{array}{l}\text { Lin et al. } \\
2021^{[19]}\end{array}$ \\
\hline 19 & Female & 5.34 & 6.02 & c.797C>T (p.P266L) & c. $394-1 G>A$ & $\begin{array}{l}\text { Lin et al. } \\
2021^{[19]}\end{array}$ \\
\hline
\end{tabular}




\begin{tabular}{|c|c|c|c|c|c|c|}
\hline $\begin{array}{l}\text { Patient } \\
\text { no. }\end{array}$ & Gender & $\mathrm{CO}$ & $\begin{array}{l}\text { C0- } \\
\text { F1 }\end{array}$ & Genotype & & References \\
\hline 20 & Female & 1.78 & 1.90 & $\begin{array}{l}\text { c.695C>T } \\
\text { (p.T232M) }\end{array}$ & c. $1139 \mathrm{C}>\mathrm{T}($ p.A380V) & $\begin{array}{l}\text { Lin et al. } \\
2021^{[19]}\end{array}$ \\
\hline 21 & Male & 4.34 & 4.45 & c.51C>G (p.F17L) & c.51C>G (p.F17L) & $\begin{array}{l}\text { Lin et al. } \\
2021^{[19]}\end{array}$ \\
\hline 22 & Female & 4.75 & 4.16 & c. $760 \mathrm{C}>\mathrm{T}\left(\mathrm{p} . \mathrm{R} 254^{\star}\right)$ & c.845G>A (p.R282Q) & $\begin{array}{l}\text { Lin et al. } \\
2021^{[19]}\end{array}$ \\
\hline 23 & Female & 3.45 & 5.24 & c. $760 \mathrm{C}>\mathrm{T}\left(\mathrm{p} . \mathrm{R} 254^{\star}\right)$ & c. $1400 \mathrm{C}>\mathrm{G}$ (p.S467C) & $\begin{array}{l}\text { Lin et al. } \\
2021^{[19]}\end{array}$ \\
\hline 24 & Female & 6.82 & 5.02 & c. $760 \mathrm{C}>\mathrm{T}\left(\mathrm{p} . \mathrm{R} 254^{\star}\right)$ & c. $1400 \mathrm{C}>\mathrm{G}$ (p.S467C) & $\begin{array}{l}\text { Lin et al. } \\
2021^{[19]}\end{array}$ \\
\hline 25 & Male & 2.19 & 2.12 & $\begin{array}{l}\text { c. } 822 G>A \\
\left(p . W 274^{\star}\right)\end{array}$ & $\begin{array}{l}\text { c.782_799del } \\
\text { ((p.V261_P266del) }\end{array}$ & $\begin{array}{l}\text { Lin et al. } \\
2021^{[19]}\end{array}$ \\
\hline 26 & Male & 2.73 & 9.84 & c.51C>G (p.F17L) & $\begin{array}{l}\text { c. } 1144 \_1162 \mathrm{del} \\
\text { (p.V382Cfs*45) }\end{array}$ & $\begin{array}{l}\text { Lin et al. } \\
2021^{[19]}\end{array}$ \\
\hline 27 & Male & 3.00 & 10.81 & c.51C>G (p.F17L) & c. $1400 \mathrm{C}>\mathrm{G}$ (p.S467C) & $\begin{array}{l}\text { Lin et al. } \\
2021^{[19]}\end{array}$ \\
\hline 28 & Male & 6.46 & 5.10 & $\begin{array}{l}\text { c.695C>T } \\
\text { (p.T232M) }\end{array}$ & c. $1400 \mathrm{C}>\mathrm{G}$ (p.S467C) & $\begin{array}{l}\text { Lin et al. } \\
2021^{[19]}\end{array}$ \\
\hline 29 & Male & 3.02 & 1.77 & c. $760 \mathrm{C}>\mathrm{T}\left(\mathrm{p} . \mathrm{R} 254^{\star}\right)$ & c.760C>T (p.R254*) & $\begin{array}{l}\text { Lin et al. } \\
2021^{[19]}\end{array}$ \\
\hline 30 & Female & 6.77 & 10.05 & $\begin{array}{l}\text { c. } 1400 C>G \\
\text { (p.S467C) }\end{array}$ & c. $1400 \mathrm{C}>\mathrm{G}$ (p.S467C) & $\begin{array}{l}\text { Lin et al. } \\
2021^{[19]}\end{array}$ \\
\hline 31 & Female & 2.36 & 1.75 & c. $760 \mathrm{C}>\mathrm{T}\left(\mathrm{p} . \mathrm{R} 254^{\star}\right)$ & c.760C>T (p.R254*) & $\begin{array}{l}\text { Lin et al. } \\
2021^{[19]}\end{array}$ \\
\hline 32 & Female & 3.12 & 2.88 & c. $760 \mathrm{C}>\mathrm{T}\left(\mathrm{p} . \mathrm{R} 254^{\star}\right)$ & c.51C>G (p.F17L) & $\begin{array}{l}\text { Lin et al. } \\
2021^{[19]}\end{array}$ \\
\hline 33 & Male & 3.64 & 3.80 & $\begin{array}{l}\text { c.695C>T } \\
\text { (p.T232M) }\end{array}$ & c.1139c>T (p.A380V) & $\begin{array}{l}\text { Lin et al. } \\
2021^{[19]}\end{array}$ \\
\hline 34 & Female & 3.56 & 4.31 & c. $760 \mathrm{C}>\mathrm{T}\left(\mathrm{p} . \mathrm{R} 254^{\star}\right)$ & c.1139c >T (p.A380V) & $\begin{array}{l}\text { Lin et al. } \\
2021^{[19]}\end{array}$ \\
\hline 35 & Female & 6.27 & 3.43 & $\begin{array}{l}\text { c.695C>T } \\
\text { (p.T232M) }\end{array}$ & c.1139c>T (p.A380V) & $\begin{array}{l}\text { Lin et al. } \\
2021^{[19]}\end{array}$ \\
\hline
\end{tabular}




\begin{tabular}{|c|c|c|c|c|c|c|}
\hline $\begin{array}{l}\text { Patient } \\
\text { no. }\end{array}$ & Gender & $\mathrm{CO}$ & $\begin{array}{l}\text { C0- } \\
\text { F1 }\end{array}$ & Genotype & & References \\
\hline 36 & Female & 2.70 & 3.46 & c. $760 \mathrm{C}>\mathrm{T}\left(\mathrm{p} . \mathrm{R} 254^{\star}\right)$ & c.51C>G (p.F17L) & $\begin{array}{l}\text { Lin et al. } \\
2021^{[19]}\end{array}$ \\
\hline 37 & Male & 7.35 & 14.27 & $\begin{array}{l}\text { c. } 338 \mathrm{G}>\mathrm{A} \\
\text { (p.C113Y) }\end{array}$ & c.338G>A (p.C113Y) & $\begin{array}{l}\text { Lin et al. } \\
2021^{[19]}\end{array}$ \\
\hline 38 & Male & 8.25 & 2.51 & c.51C>G (p.F17L) & c.338G>A (p.C113Y) & $\begin{array}{l}\text { Lin et al. } \\
2019^{[24]}\end{array}$ \\
\hline 39 & Male & 2.45 & 1.14 & c. $760 \mathrm{C}>\mathrm{T}\left(\mathrm{p} . \mathrm{R} 254^{\star}\right)$ & c.760C >T (p.R254*) & $\begin{array}{l}\text { Lin et al. } \\
2019^{[24]}\end{array}$ \\
\hline 40 & Male & 2.8 & 1.74 & c. $760 \mathrm{C}>\mathrm{T}\left(\mathrm{p} . \mathrm{R} 254^{\star}\right)$ & c. $1161 T>G($ p.Y387*) & $\begin{array}{l}\text { Lin et al. } \\
2019^{[24]}\end{array}$ \\
\hline 41 & Female & 6.83 & 4.59 & c. $760 \mathrm{C}>\mathrm{T}\left(\mathrm{p} . \mathrm{R} 254^{\star}\right)$ & c. $1400 \mathrm{C}>\mathrm{G}(\mathrm{p} . \mathrm{S} 467 \mathrm{C})$ & $\begin{array}{l}\text { Lin et al. } \\
2019^{[24]}\end{array}$ \\
\hline 42 & Female & 6.22 & 11.14 & c. $760 \mathrm{C}>\mathrm{T}\left(\mathrm{p} . \mathrm{R} 254^{\star}\right)$ & c. $1400 \mathrm{C}>\mathrm{G}(\mathrm{p} . \mathrm{S} 467 \mathrm{C})$ & $\begin{array}{l}\text { Lin et al. } \\
2019^{[24]}\end{array}$ \\
\hline 43 & Female & 6.16 & 4.02 & c.695C>T(p.T232M) & c. $1400 \mathrm{C}>\mathrm{G}(\mathrm{p} . \mathrm{S} 467 \mathrm{C})$ & $\begin{array}{l}\text { Lin et al. } \\
2019^{[24]}\end{array}$ \\
\hline 44 & Male & 6.77 & 4.5 & c. $760 \mathrm{C}>\mathrm{T}\left(\mathrm{p} . \mathrm{R} 254^{\star}\right)$ & c. $1400 \mathrm{C}>\mathrm{G}($ p.S467C) & $\begin{array}{l}\text { Lin et al. } \\
2019^{[24]}\end{array}$ \\
\hline 45 & Female & 4.91 & 6.66 & c. $250 \mathrm{~T}>\mathrm{A}(\mathrm{p} . \mathrm{Y} 84 \mathrm{~N})$ & c. $1400 \mathrm{C}>\mathrm{G}(\mathrm{p} . \mathrm{S} 467 \mathrm{C})$ & $\begin{array}{l}\text { Lin et al. } \\
2019^{[24]}\end{array}$ \\
\hline 46 & Male & 3.24 & 4.05 & c.51C>G (p.F17L) & c.1196G>A(p.R399Q) & $\begin{array}{l}\text { Lin et al. } \\
2019^{[24]}\end{array}$ \\
\hline 47 & Male & 4.96 & 5 & c.51C>G (p.F17L) & c.1195C>T(p.R399W) & $\begin{array}{l}\text { Lin et al. } \\
2019^{[24]}\end{array}$ \\
\hline 48 & Female & 3.15 & 4.09 & c.760C >T (p.R254*) & c. $1400 \mathrm{C}>\mathrm{G}(\mathrm{p} . \mathrm{S} 467 \mathrm{C})$ & $\begin{array}{l}\text { Lin et al. } \\
2019^{[24]}\end{array}$ \\
\hline 49 & Female & 4.12 & 1.29 & c. $760 \mathrm{C}>\mathrm{T}\left(\mathrm{p} . \mathrm{R} 254^{\star}\right)$ & c.760C >T (p.R254*) & $\begin{array}{l}\text { Lin et al. } \\
2019^{[24]}\end{array}$ \\
\hline \multicolumn{7}{|c|}{ C0: free carnitine detected at newborn screening, $\mathrm{C} 0-\mathrm{F} 1: \mathrm{C} 0$ retested at recall stage, cutoff value: $8.5-$} \\
\hline
\end{tabular}

\section{SLC22A5 variants and allele distributions}

Forty-nine patients with biallelic pathogenic variants in the SLC22A5 gene were eventually diagnosed with PCD. A total of 19 distinct SLC22A5 variants were detected in the 49 patients. Among which $63.2 \%$ 
(12/19) were missense, $21.1 \%$ (4/19) were nonsense, $10.5 \%$ (2/19) were frameshift variants, and 5.3\% $(1 / 19)$ affected spicing. All variants have been previously reported, most of the detected variants were clustered in exons 1,4 , and 7 . The most common variant was c.760C $>T$ (p.R254*) with an allele frequency of $31.63 \%$, followed by c.51C>G (p.F17L) (17.35\%) and c. $1400 \mathrm{C}>\mathrm{G}$ (p.S467C) $(16.33 \%)$. The other relatively common variants were c.695C >T (p.T232M), c.338G >A (p.C113Y), c.1139C>T (p.A380V), c.797C>T (p.P266L), and c.1195C>T (p.R399W). These eight variants together accounted for $86.73 \%$ $(85 / 98)$ of all mutated alleles (Table 2$)$.

Table 2

SLC22A5 variants and allele distributions in patients with PCD

\begin{tabular}{|c|c|c|c|c|c|}
\hline No. & Location & Variants & $\begin{array}{l}\text { Variant } \\
\text { type }\end{array}$ & $\begin{array}{l}\text { Mutant allele } \\
\text { (No.) }\end{array}$ & $\begin{array}{l}\text { Allele frequency } \\
(\%)\end{array}$ \\
\hline 1 & Exon 4 & c.760C >T (p.R254*) & Nonsense & 31 & 31.63 \\
\hline 2 & Exon 8 & c. $1400 \mathrm{C}>\mathrm{G}(\mathrm{p} . \mathrm{S} 467 \mathrm{C})$ & Missense & 16 & 16.33 \\
\hline 3 & Exon 1 & c.51C>G (p.F17L) & Missense & 17 & 17.35 \\
\hline 4 & Exon 4 & c.695C>T (p.T232M) & Missense & 7 & 7.14 \\
\hline 5 & Exon 1 & c.338G >A (p.C113Y) & Missense & 4 & 4.08 \\
\hline 6 & Exon 7 & c. $1139 \mathrm{C}>\mathrm{T}$ (p.A380V) & Missense & 4 & 4.08 \\
\hline 7 & Exon 4 & c.797C>T (p.P266L) & Missense & 3 & 3.06 \\
\hline 8 & Exon 7 & c.1195C>T (p.R399W) & Missense & 3 & 3.06 \\
\hline 9 & Exon 2 & c.428c>T (p.P143L) & Missense & 2 & 2.04 \\
\hline 10 & Exon 7 & c. $1161 T>G\left(p . Y 387^{\star}\right)$ & Nonsense & 2 & 2.04 \\
\hline 11 & Exon 1 & c. $250 \mathrm{~T}>\mathrm{A}(\mathrm{p} . \mathrm{Y} 84 \mathrm{~N})$ & Missense & 1 & 1.02 \\
\hline 12 & Intron 1 & c. $394-1 G>A$ & Splice & 1 & 1.02 \\
\hline 13 & Exon 4 & $\begin{array}{l}\text { c.782_799del } \\
\text { (p.V261_P266del) }\end{array}$ & Frameshift & 1 & 1.02 \\
\hline 14 & Exon 7 & $\begin{array}{l}\text { c. } 1144-1162 \text { del } \\
\text { (p.V382Cfs*45) }\end{array}$ & Frameshift & 1 & 1.02 \\
\hline 15 & Exon 4 & $c .822 \mathrm{G}>\mathrm{A}\left(\mathrm{p} . \mathrm{W} 274^{*}\right)$ & Nonsense & 1 & 1.02 \\
\hline 16 & Exon 5 & c.844C>T (p.R282*) & Nonsense & 1 & 1.02 \\
\hline 17 & Exon 5 & c.845G>A (p.R282Q) & Missense & 1 & 1.02 \\
\hline 18 & Exon 7 & c. $1160 A>G(p . Y 387 C)$ & Missense & 1 & 1.02 \\
\hline 19 & Exon 7 & c.1196G>A (p.R399Q) & Missense & 1 & 1.02 \\
\hline Total & & & & 98 & 100.00 \\
\hline
\end{tabular}




\section{Relationship Between Genotype And Biochemical Phenotype}

The PCD patients were divided into three groups: (i) N/N (null/null, $n=8$ ), (ii) N/M (null/missense, $n=22$ ), and (iii) $M / M$ (missense/missense, $n=19$ ). As shown in Figure $1 a$, the median of $N / N, N / M$, and $M / M$ groups was $2.43,3.53$, and 5.02, respectively. The $\mathrm{C} 0$ level of patients with $\mathrm{N} / \mathrm{N}$ genotype was significantly lower than that of $M / M$ group $(P=0.001)$. Patients with $N / N$ genotype also had low $C 0$ level compared to the N/M group, while no significant difference was observed $(P=0.055)$. The $C 0$ level was no significant difference between $N / M$ and $M / M$ groups $(P=0.304)$.

Besides, patients with c.760C $>T$ (p.R254*) and two other common variants were grouped. There were six patients with genotype of R254*/R254*, four patients with genotype of R254*/F17L, and eight patients with genotype of R254*/S467C. The mean $\mathrm{CO}$ level in patients with genotypes of R254*/R254*, $\mathrm{R} 254 * / F 17 \mathrm{~L}$, and $\mathrm{R} 254 * / \mathrm{S} 467 \mathrm{C}$ was $2.66 \pm 0.84,2.82 \pm 0.66$, and $5.32 \pm 1.61 \mu \mathrm{mol} / \mathrm{L}$, respectively. The C0 level of patients with genotypes of R254*/R254* and R254*/F17L were far lower than patients with genotype of R254*/S467C ( $P=0.001$ and $P=0.005$, respectively) (Figure 1b).

\section{Discussion}

PCD is the most common fatty acid metabolic disorder in China. NBS for PCD has been successfully implemented in most parts of China, patients usually had better prognosis following early L-carnitine therapy. The incidence of PCD varies greatly throughout China, ranging from 1:8,938 to 1:48,717 [13-15]. The largest scale NBS study in China showed that the incidence of PCD was 1:30,182 in Zhejiang province [8]. This study presented more than 500,000 NBS data, indicating that the latest incidence in Quanzhou area was 1:11,189, which is similar to the incidence recently reported in Guangzhou $(1: 13,345)$ and Ningbo $(1: 16,595)$ areas $[15,16]$. It is noteworthy that the actual incidence of PCD should be higher since current MS/MS-based NBS with poor sensitivity $[17,18]$.

NBS results showed that all patients with low CO levels, while some patients may have normal C0 levels during recall review. These patients would have been excluded from conventional NBS, but could be identified by incorporating second-tier genetic screening [19]. However, it is noteworthy that PCD patients are also easily missed during NBS because the $\mathrm{CO}$ levels at birth could be affected by the maternal concentration and therefore cannot reflect the true levels of the newborns themselves. Luo et al. recently conducted a pilot study in which genetic screening was performed on only 1,127 neonates using targeted NGS, and one PCD case of false-negative ( $C 0=11.6 \mu \mathrm{mol} / L)$ was identified [20]. Therefore, NBS for PCD NBS is facing challenges, and it is necessary to combine genetic testing to improve screening efficiency.

This study have updated the SLC22A5 variant spectrum of a southern Chinese population. The top eight variants together had an allele frequency of $86.73 \%$, which provided an important evidence for the rapid screening of targeted SLC22A5 variants in the Chinese population. Many studies have shown that c.51C>G (p.F17L), c.760C >T (p.R254*), and c.1400C >G (p.S467C) are the three most common variants in 
the Chinese population, but which variant has the highest frequency varies among diverse regions. For instance, c.1400C>G (p.S467C) was the most frequent variant in Jining, Suzhou, Guangzhou, Xuzhou, and Ningbo areas $[12,15,16,21,22]$; c.51C>G (p.F17L) was the most common variant in Liuzhou area [23]. By contrast, our data revealed that c.760C $>T$ (p.R254*) was the most common variant in this cohort of patients, and its allele frequency was almost equal to the sum of the other two variants. c.760C $>T$ (p.R254*) is a loss-of-function variant that can cause severe clinical symptoms, it was common in southern China but was rarely detected in northern China [14, 22, 24-26], indicating this variant presented different geographic distribution. Whereas c.1400C > G (p.S467C) with residual function may result in a milder phenotype, it was common in both southern and northern China [14, 22, 24, 26], suggesting this variant was common in the general Chinese population.

Regarding the relationship between genotype and biochemical phenotype, significant difference was observed in CO levels between patients with $\mathrm{N} / \mathrm{N}$ and $\mathrm{M} / \mathrm{M}$ genotypes, and most patients with N/N genotype had low $\mathrm{CO}$ levels compared to the N/M group, indicating patients with null variants were associated with low CO levels. Notably, patients with N/M genotype may also have very low C0 levels if the missense variant with significantly impaired transport activity. As demonstrated in Figure 1b, no significant difference was observed in CO levels between patients with genotypes of R254*/R254* and R254*/F17L. In contrast, significant difference was observed in C0 levels between patients with genotypes of R254*/R254* and R254*/S467C because c.1400C>G (p.S467C) retained residual carnitine transport activity.

In summary, this study presented more than 500,000 NBS data with the latest incidence of $1: 11,189$ in Quanzhou area. The SLC22A5 variant spectrum in the selected southern Chinese population was updated, the top eight variants together had an allele frequency of $86.73 \%$, and c.760C>T (p.R254*) was the most common variant. Patients with null variants were associated with low CO levels. It is necessary to combine genetic testing to improve screening efficiency due to PCD patients may have normal $C 0$ levels during NBS and recall review.

\section{Abbreviations}

PCD: primary carnitine deficiency; OCTN2: organic cation transporter type 2; NBS: newborn screening; MS/MS: tandem mass spectrometry; CO: free carnitine; NGS: next-generation sequencing; $\mathrm{N} / \mathrm{N}$ : null/null; N/M: null/missense; M/M: missense/missense.

\section{Declarations}

\section{Ethics approval and consent to participate}

This study was approved by the Ethical Committee of Quanzhou Maternity and Children's Hospital and was performed in accordance with the Declaration of Helsinki. Written informed consent was obtained from the parents of all infants for collection of samples and publication of medical data. 


\section{Consent for publication}

Consent was obtained from the parents of all patients for publication.

\section{Availability of data and materials}

The datasets used and/or analysed during the current study can be obtained from the corresponding author upon a reasonable request.

\section{Conflict of Interest}

The authors declare that they have no conflicts of interest.

\section{Details of funding}

This work was funded by the Natural Science Foundation of Fujian province (Grant No. 2020J01130 and 2021 J01538) and the Youth Research Project in the Health System of Fujian Province (Grant No. 2020QNA083).

\section{Author contributions}

YM Lin performed the data analysis, drafted and revised the manuscript; BB Lin performed the statistical analyses; YR Chen, ZZ Zheng, and QL Fu followed the patients and collected the clinical data; WF Zhang assisted with data collection, reviewed and revised the manuscript; WH Lin supervised the research study. All authors read and approved the final manuscript.

\section{Acknowledgements}

We thank all the participants for their help and support. We would like to thank Editage (www.editage.cn) for English language editing.

\section{References}

1. Nezu J, Tamai I, Oku A, Ohashi R, Yabuuchi H, Hashimoto N, et al. Primary systemic carnitine deficiency is caused by mutations in a gene encoding sodium ion-dependent carnitine transporter. Nat Genet. 1999;21(1):91-4.

2. Tang NL, Ganapathy V, Wu X, Hui J, Seth P, Yuen PM, et al. Mutations of OCTN2, an organic cation/carnitine transporter, lead to deficient cellular carnitine uptake in primary carnitine deficiency. Hum Mol Genet. 1999;8(4):655-60.

3. Verbeeten KC, Lamhonwah AM, Bulman D, Faghfoury H, Chakraborty P, Tein I, et al. Carnitine uptake defect due to a 5'UTR mutation in a pedigree with false positives and false negatives on Newborn screening. Mol Genet Metab 2019. 
4. Longo N. Primary Carnitine Deficiency and Newborn Screening for Disorders of the Carnitine Cycle. Ann Nutr Metab. 2016;68(Suppl 3):5-9.

5. Magoulas PL, El-Hattab AW. Systemic primary carnitine deficiency: an overview of clinical manifestations, diagnosis, and management. Orphanet J Rare Dis. 2012;7:68.

6. El-Hattab AW, Li FY, Shen J, Powell BR, Bawle EV, Adams DJ, et al. Maternal systemic primary carnitine deficiency uncovered by newborn screening: clinical, biochemical, and molecular aspects. Genet Med. 2010;12(1):19-24.

7. Rasmussen J, Duno M, Lund AM, Steuerwald U, Hansen SH, Joensen HD, et al. Increased risk of sudden death in untreated Primary Carnitine Deficiency. J Inherit Metab Dis 2019.

8. Lin $Y, X u H, Z$ hou D, Hu Z, Zhang C, Hu L, et al. Screening 3.4 million newborns for primary carnitine deficiency in Zhejiang Province, China. Clin Chim Acta. 2020;507:199-204.

9. Frigeni M, Balakrishnan B, Yin X, Calderon FRO, Mao R, Pasquali M, et al. Functional and molecular studies in primary carnitine deficiency. Hum Mutat. 2017;38(12):1684-99.

10. Lin Y, Lin W, Chen Y, Lin C, Zheng Z, Zhuang J, et al. Combined primary carnitine deficiency with neonatal intrahepatic cholestasis caused by citrin deficiency in a Chinese newborn. BMC Pediatr. 2020;20(1):478.

11. Zhang Y, Li H, Liu J, Yan H, Liu Q, Wei X, et al. Molecular investigation in Chinese patients with primary carnitine deficiency. Mol Genet Genomic Med. 2019;7(9):e901.

12. Zhou W, Li H, Huang T, Zhang Y, Wang C, Gu M. Biochemical, Molecular, and Clinical Characterization of Patients With Primary Carnitine Deficiency via Large-Scale Newborn Screening in Xuzhou Area. Front Pediatr. 2019;7:50.

13. Sun $Y$, Wang YY, Jiang T. Clinical features and genotyping of patients with primary carnitine deficiency identified by newborn screening. J Pediatr Endocrinol Metab. 2017;30(8):879-83.

14. Zhang R, Qiang R, Song C, Ma X, Zhang Y, Li F, et al. Spectrum analysis of inborn errors of metabolism for expanded newborn screening in a northwestern Chinese population. Sci Rep. 2021;11(1):2699.

15. Yang X, Li Q, Wang F, Yan L, Zhuang D, Qiu H, et al. Newborn Screening and Genetic Analysis Identify Six Novel Genetic Variants for Primary Carnitine Deficiency in Ningbo Area, China. Front Genet. 2021;12:686137.

16. Huang YL, Tang CF, Liu SC, Sheng HY, Tang F, Jiang X, et al. [Newborn screening for primary carnitine deficiency and variant spectrum of SLC22A5 gene in Guangzhou]. Zhonghua Er Ke Za Zhi. 2020;58(6):476-81.

17. Wilson C, Knoll D, de Hora M, Kyle C, Glamuzina E, Webster D. The decision to discontinue screening for carnitine uptake disorder in New Zealand. J Inherit Metab Dis. 2019;42(1):86-92.

18. Verbeeten KC, Lamhonwah AM, Bulman D, Faghfoury H, Chakraborty P, Tein I, et al. Carnitine uptake defect due to a $5^{\prime}$ UTR mutation in a pedigree with false positives and false negatives on Newborn screening. Mol Genet Metab. 2020;129(3):213-8. 
19. Lin Y, Zhang W, Huang C, Lin C, Lin W, Peng W, et al. Increased detection of primary carnitine deficiency through second-tier newborn genetic screening. Orphanet J Rare Dis. 2021;16(1):149.

20. Luo X, Sun Y, Xu F, Guo J, Li L, Lin Z, et al. A pilot study of expanded newborn screening for 573 genes related to severe inherited disorders in China: results from 1,127 newborns. Ann Transl Med. 2020;8(17):1058.

21. Wang T, Ma J, Zhang Q, Gao A, Wang Q, Li H, et al. Expanded Newborn Screening for Inborn Errors of Metabolism by Tandem Mass Spectrometry in Suzhou, China: Disease Spectrum, Prevalence, Genetic Characteristics in a Chinese Population. Front Genet. 2019;10:1052.

22. Yang $C$, Zhou C, Xu P, Jin X, Liu W, Wang W, et al. Newborn screening and diagnosis of inborn errors of metabolism: A 5-year study in an eastern Chinese population. Clin Chim Acta. 2020;502:133-8.

23. Tan J, Chen D, Chang R, Pan L, Yang J, Yuan D, et al. Tandem Mass Spectrometry Screening for Inborn Errors of Metabolism in Newborns and High-Risk Infants in Southern China: Disease Spectrum and Genetic Characteristics in a Chinese Population. Front Genet. 2021;12:631688.

24. Lin Y, Zheng Q, Zheng T, Zheng Z, Lin W, Fu Q. Expanded newborn screening for inherited metabolic disorders and genetic characteristics in a southern Chinese population. Clin Chim Acta. 2019;494:106-11.

25. Tang NL, Hwu WL, Chan RT, Law LK, Fung LM, Zhang WM. A founder mutation (R254X) of SLC22A5 (OCTN2) in Chinese primary carnitine deficiency patients. Hum Mutat. 2002;20(3):232.

26. Lee NC, Tang NL, Chien YH, Chen CA, Lin SJ, Chiu PC, et al. Diagnoses of newborns and mothers with carnitine uptake defects through newborn screening. Mol Genet Metab. 2010;100(1):46-50.

27. Lin Y, Wang W, Lin C, Zheng Z, Fu Q, Peng W, et al. Biochemical and molecular features of Chinese patients with glutaric acidemia type 1 detected through newborn screening. Orphanet J Rare Dis. 2021;16(1):339.

\section{Figures}
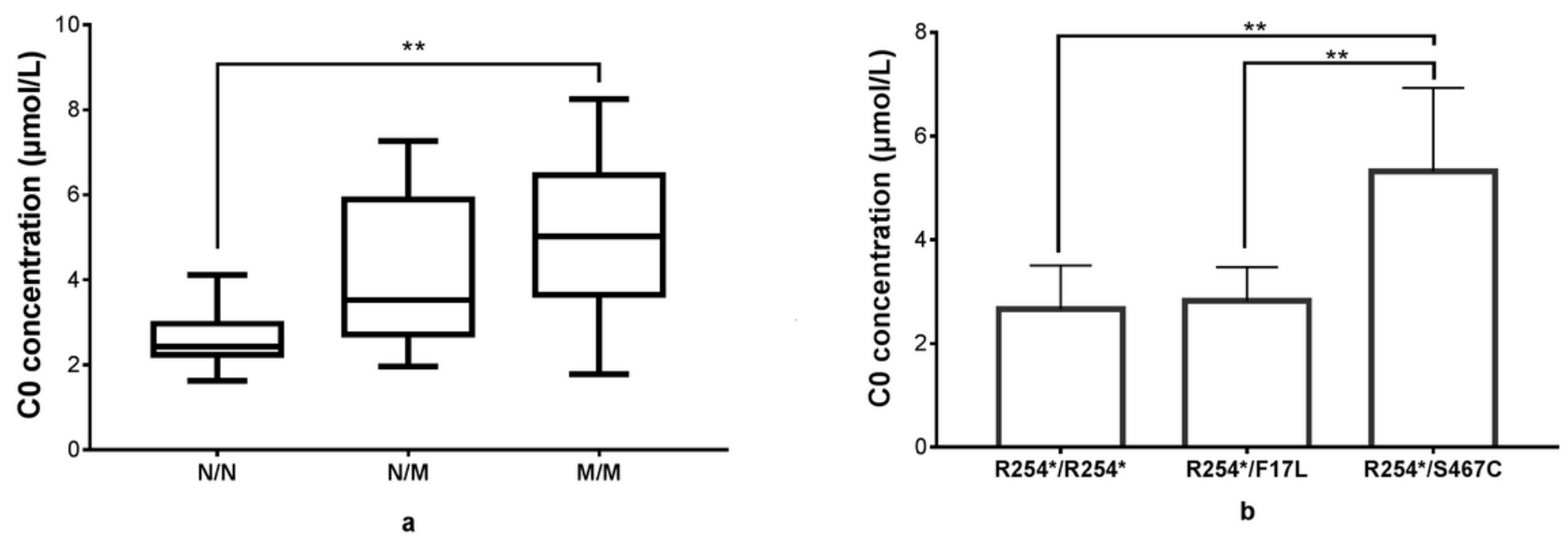


\section{Figure 1}

Comparison of the $\mathrm{CO}$ concentrations ( $\mu \mathrm{mol} / \mathrm{L}$ ) in PCD patients with different genotypes. N/N: null/null; N/M: null/missense; M/M: missense/missense. Statistically significant differences are indicated by asterisks ( $\left.{ }^{*}<0.05 ;{ }^{*} \mathrm{P}<0.01 ; * \star \star \mathrm{P}<0.001\right)$ above a bracket connecting two groups. 